\title{
Diversity of bryophyte flora and vegetation on rotten wood in rain and montane forests of northeastern Tanzania
}

\author{
Päivi Mattila \\ Timo Koponen \\ Department of Ecology and Systematics, Division of Systematic Biology, P. O. Box 7, FIN- \\ 00014 University of Helsinki, Finland
}

\begin{abstract}
Decomposing wood forms the substrate for special lignicolous, hygrophilous, and sciophilous plant communities. In a moist tropical forest, vegetation on this substrate consists mostly of bryophytes. The material gathered from Mt. Meru and the Usambara Mts. in Tanzania comprises 102 taxa or genera of bryophytes. Of these 86 taxa are mosses and 16 hepatics. They were collected from a number of rotten logs at different stages of decay both in primeval and in cultivated forests. The bryophyte vegetation on these logs was examined by use of quadrats $20 \times 20 \mathrm{~cm}$. A total of 71 taxa occurred in 51 plots.
\end{abstract}

In the Usambaras, 38 species of bryophytes were recorded and 73 on Mt. Meru, all on rotten wood. Within each of 16 study areas the smallest number of taxa observed was 5 and the highest 37 in the natural forest on the east slope of Mt. Meru. Only three genera of hepatics and three species of mosses occurred both in the Usambaras and on Mt. Meru. Most of the taxa on rotten wood are rare; $42 \%$ of them were found on only one plot. Similarity indexes show that the bryophyte associations on Mt. Meru and in the Usambaras and the associations in the natural forests and cultivated forests on Mt. Meru are very different. Associations on natural forests on the east and west slopes of Mt. Meru show some similarity. The bryophyte associations on rotten wood coincide with the altitudinal zonation of montane forests: the associations at different altitudes differ, as does the structure of the vegetation. The bryophyte taxa represent 9 different life forms, with the weft form most frequent. At low elevations in the Usambaras, weft and mat forms are most common, while in primeval forests on Mt. Meru no life form is dominant. In the highest montane forests more life forms occur than at lower elevations.

Differences in the flora and vegetation of rotten wood of the 16 study areas can be explained by differences in the intensity of the study, by climatological parameters and soils, and for historical reasons.

The results, although preliminary, seem to indicate that within rather short distances quite different floras and associations occur on rotten 
wood in northeastern Tanzania. Moreover, the floras of planted monocultures are quite different from the floras of primeval forest. These facts must be considered in the planning for preservation of biological diversity.

\section{INTRODUCTION}

This is a study of bryophytes on decaying logs in more or less undisturbed submontane rain forests, in dry and moist montane forests, and in cultivated forests in northeastern Tanzania. We wanted to determine which species occur on rotten wood, what kind of communities they form, and what patterns of succession occur during decomposition. In the bryophyte communities, we studied the life forms of the constituent species.

To our knowledge not many published studies yet exist concerning bryophyte communities on rotten wood in the tropics (see Sastre-De Jesús 1992). Only general remarks on this kind of vegetation appear in handbooks (Pócs 1982, Richards 1984).

\section{MATERIAL AND METHODS}

Material for this study was collected during a field excursion organized jointly by the Department of Botany of the University of Helsinki (Finland) and Sokoine University of Agriculture (Morogoro, Tanzania), in December, 1988. Detailed information on the project and the expedition plus students' research reports are in Koponen et al. (1990). Descriptions of the vegetation and flora of some of our study areas are in Kiirikki (1990), Pócs (1990a, 1990b) and Tuomisto (1990).

\section{Study areas}

Here we describe our 7 study areas and 16 study sites. More detailed information is to be found in Koponen et al. (1990). We supply here also the collection-site numbering for the HelsinkiSokoine Expedition (Koponen et al. 1990), which are given on the labels of the voucher specimens

\section{Study Area 1}

Study site 1

Tanga Province, Lushoto District, East Usambara Mts. Amani, submontane rain forest at R. Bulwa, alt. c. $780 \mathrm{~m}$. Canopy cover $20 \%$, slope $5 \mathrm{E}$ E, logs 4-6, sample plots 14-20, 9.XII.1988 (collection site 18d).

\section{Study Area 2.}

Study site 2

Tanga Province, Lushoto District, East Usambara Mts. Amani Forest Reserve, submontane rain forest, alt. c. $950 \mathrm{~m}$. Canopy cover 40-90\%, slope 5-8E SW, logs 1-3, plots 1-13, 8.-9.XII.1988 (collection site 18b).

\section{Study Area 3}

Tanga Province, Lushoto District, West Usambara Mts. Magamba village $\mathrm{N}$ of Lushoto, alt. $1800-1900 \mathrm{~m}$.

\section{Study site $3 a$}

Secondary dry lower montane forest (dominated by Ocotea usambarensis) $\mathrm{W}$ of the village. Canopy cover $80 \%$, slope $1 \mathrm{E}, \log 7$, sample plots 21-22, 11.XII.1988 (collection site 12d).

\section{Study site $3 b$}

Shume-Magamba forest reserve N of Lushoto; closed, old, lower montane forest. Canopy cover 90\%, slope 6-8E E, 20.XII.1988 (collection sites $12 \mathrm{~h}$ and $12 \mathrm{i}$ ).

\section{Study Area 4}

Arusha (Northern) Province, Arusha District. Western foot of Mt. Meru, Olmotonyi, training forest of the Sokoine University of Agriculture, alt. 1 830-2 110 m, 13.XII.1988.

Study site $4 a$

Shady c. 20-year-old stand of Cupressus lusitanica on gently rising SSW slope (in/around sample plots 1 and 2 in Kiirikki, 1990), alt. 1 830 m. Canopy cover 60\%, slope 6-8E S, logs 89, sample plots 23-25 (collecting site 2a). 
Study site $4 b$

Approximately 20-year-old stand of planted Grevillea robusta (in/around sample plot 3 in Kiirikki, 1990), alt. 1950 m. Canopy cover 70\%, slope 6E S, logs 10-11, sample plots 26-27 (collecting site $2 \mathrm{~b}$ ).

Study site $4 c$

Approximately 20-year-old stand of Eucalyptus saligna (in/around plot 6 in Kiirikki, 1990), alt. $2010 \mathrm{~m}$. Canopy cover 50\%, slope 20E, logs 14-15, somple plots 29-30 (collecting site 2e).

Study site $4 d$

Approximately 20-year-old stand of Pinus patula (plot 4 in Kiirikki, 1990), alt. 2110 m. Canopy cover $60 \%$. slope $5 \mathrm{E} \mathrm{W}, \log 13$, sample plot 28 (collecting site $2 \mathrm{c}$ ).

\section{Study Area 5}

Arusha (Northern) Province, Arusha District. Western side of Mt. Meru above Laikinoi, ridge between the streams Engare Olmotonyi and Engare Narok, primeval forests at 2 480-2 800 m, 14.-15.XII.1988.

\section{Study site $5 a$}

Hagenia abyssinica forest on SW slope, (plot 7 in Tuomisto, 1990), alt. $2480 \mathrm{~m}$. Canopy cover $90 \%$, slope $30 \mathrm{E}$ SSW, logs $16-17$, sample plots 31-32 (collecting site $2 \mathrm{~g}$ ).

\section{Study site $5 b$}

Juniperus excelsa (J. procera) forest (plot 8 in Tuomisto, 1990), alt. $2600 \mathrm{~m}$. Canopy cover $80 \%$, slope $30 \mathrm{ESE}, \log 18$, sample plots 33-36 (collecting site $2 \mathrm{~h}$ ).

\section{Study site 5c}

Hagenia abyssinica forest (plot 9 in Tuomisto, 1990), alt. $2700-2800$ m. Canopy cover 60\%, slope $15 \mathrm{E}$ SW, $\log 20$, sample plots $37-38$ (collecting site $2 \mathrm{k}$ ).

\section{Study Area 6}

Arusha (Northern) Province, Arusha District. Western side of Mt. Meru above Laikinoi, ridge between the streams Engare Olmotonyi and Engare Narok, near upper limit of primeval Hagenia abyssinica forest, alt. 2 990-3 210 m, 14.-

\section{XII.1988.}

Study site $6 a$

Hagenia-Stoebe kilimandscharica forest (plot 10 in Tuomisto, 1990), alt. $2990 \mathrm{~m}$. Canopy cover $30 \%$, slope 20E SWW, logs 21-23, sample plots 39-41 (collecting site 21).

\section{Study site $6 b$}

Dense 2-3 m high Stoebe kilimandscharica Helichrysum thicket (plot 11 in Tuomisto, 1990), alt. 3210 m. Canopy cover $30 \%$, slope c. 45E $\mathrm{W}, \operatorname{logs} 24-25$, sample plots 42-44 (collecting site $2 \mathrm{~m})$.

\section{Study Area 7}

Arusha (Northern) Province, Arusha District. Arusha National Park, primeval forests on E slope of Mt. Meru, alt. 2 370-2 600 m.

\section{Study site $7 a$}

At the road to the caldera of Mt. Meru, dry Podocarpus - Juniperus excelsa (J. procera) forest, alt. $2370 \mathrm{~m}$. Canopy cover $40 \%$, slope 0E, $\log 26$, sample plot 45. 16.XII. 1988 (collecting site $3 \mathrm{q}$ ).

\section{Study site $7 b$}

Podocarpus-Juniperus forest on the rim of caldera between the Kitoto campsite and View Point, alt. 2 480-2 600 m. Canopy cover 50\%, logs 27-28, sample plots 46-48, 17.XII.1988 (collecting sites $3 \mathrm{~m}, 3 \mathrm{p}$ ).

\section{Study site $7 c$}

Podocarpus-Juniperinus forest on the road between the Njeku and Kitoto campsites, alt. 2 540-2 570 m. Canopy cover 30\%, slope 0E E, $\log 29$, sample plot 49, 17.XII.1988 (collecting site 31 ).

\section{Logs studied}

We studied 27 logs or rotten stumps of various sizes with a basal diameter between 0.1 and 1.3 $\mathrm{m}$ (Table 1). These logs were measured and their stage of decay estimated visually as follows (see McCullough 1948, Muhle \& LeBlanc 1975): 
Table 1. Ecological parameters for 27 rotten logs (minus 12 and 19) or stumps (s!) used for study of bryophyte vegetation in northeastern Tanzania. 1. Direction of slope. 2. Cover \% of tree crowns. 3 Length of $\log$ or stump in meters. 4. Diameter of $\log$ in meters. 5. Stage of decay. 6. Total cover of vascular plants, \%. 7. Cover of bryophytes, \%. 8. Cover of lichens, \%. 9. Cover of fungi, \%.

\begin{tabular}{|c|c|c|c|c|c|c|c|c|c|}
\hline $\begin{array}{l}\log \\
\text { no. }\end{array}$ & 1. & 2. & 3. & 4. & 5. & 6. & 7. & 8. & 9. \\
\hline 1 & $S$ & 40 & 15 & 1,0 & $I-I I$ & 1 & 70 & + & 1 \\
\hline 2 & $\mathrm{~W}$ & 80 & 20 & 0,6 & III & + & 10 & - & + \\
\hline 3 & $\mathrm{~W}$ & 90 & 15 & 0,8 & III-IV & 5 & 50 & - & 1 \\
\hline 4 & $E$ & 20 & 4 & 1,3 & II-III & 10 & 40 & + & + \\
\hline 5 & $E$ & 20 & 5 & 1,3 & II-III & 10 & 30 & + & + \\
\hline 6 & $E$ & 20 & 10 & 0,8 & II-III & 1 & 95 & + & + \\
\hline 7 & $\mathrm{~W}$ & 40 & 4 & 0,4 & III & + & 20 & - & + \\
\hline 8 & $\mathrm{~W}$ & 60 & 0,3 & 0,4 & II-III & + & 30 & + & + \\
\hline 9 & $\mathrm{~W}$ & 60 & 0,3 & 0.4 & II-III & + & 30 & + & + \\
\hline 10 & $W$ & 70 & 50 & 0,2 & II-III & + & 5 & + & + \\
\hline 11 & $\mathrm{~W}$ & 70 & 0,3 & 0,2 & IV & + & 40 & + & + \\
\hline 13 & $W$ & 60 & 1,0 & 0,2 & $I-I I$ & + & 30 & + & + \\
\hline 14 & $\mathrm{~W}$ & 50 & 0,4 & 0,4 & II-III & + & 30 & + & + \\
\hline 15 & $\mathrm{~W}$ & 50 & 8 & 0,3 & II & 3 & 10 & + & + \\
\hline 16 & $\mathrm{~W}$ & 90 & 0,5 & 0,1 & III & + & 30 & + & + \\
\hline 17 & $\mathrm{~W}$ & 90 & 70 & 0,4 & I & 5 & 40 & + & + \\
\hline 18 & $\mathrm{~W}$ & 80 & 15 & 0,6 & $I-I I$ & + & 30 & + & + \\
\hline 20 & $\mathrm{~W}$ & 80 & 7 & 0,5 & III & + & 30 & + & + \\
\hline 21 & $W$ & 30 & 8 & 0,5 & II & + & 40 & + & + \\
\hline 22 & $\mathrm{~W}$ & 30 & 8 & 0,6 & II & + & 30 & + & + \\
\hline 23 & W & 30 & 7 & 0,3 & III & + & 50 & 5 & + \\
\hline 24 & $\mathrm{~W}$ & - & 7 & 0,2 & IV & + & 40 & + & + \\
\hline 25 & $\mathrm{~W}$ & - & 2 & 0,1 & II-III & + & 40 & + & + \\
\hline 26 & $E$ & 60 & 15 & 1,0 & IV-V & 30 & 30 & + & + \\
\hline 27 & $E$ & 60 & 5 & 0,1 & II-III & + & 30 & + & + \\
\hline 28 & $E$ & 60 & 5 & 0,1 & II-III & + & 30 & + & + \\
\hline 29 & $E$ & 60 & 8 & 0,7 & III & + & 30 & + & + \\
\hline
\end{tabular}

I: Wood hard, knife penetrates the texture hardly at all; bark usually intact.

II: Wood hard, knife penetrates it for some centimeters.

III: Wood quite soft, knife penetrates it easily for many centimeters; bark partly absent.

IV: Wood soft, breaking into pieces, knife penetrates it up to the handle; bark absent.

V: Log completely rotten, very soft and breaking up.
We also collected certain ecological data, such as the exposition of the site and the coverage of the canopy. We also estimated the total coverage of epixylic species on the logs according to following groups: vascular plants, bryophytes, lichens, fungi (Table 1). In addition, bryophytes growing on decaying substrates were collected elsewhere from study sites. All the taxa collected from rotten wood are presented in Table 2.

Table 2. Presence (x) of bryophyte taxa sampled on rotten wood from 16 study sites (1-7c) in the Usambaras and on Mt. Meru in northeastern Tanzania. 
In addition, from each $\log$ a sample of rotten wood was taken for measuring $\mathrm{pH}$. These rotten wood samples were dried, together with the bryophyte specimens, and $\mathrm{pH}$ was measured later in the laboratory in Helsinki by the following procedure: 3 gr rotten wood was soaked in $30 \mathrm{ml}$ deionized water. The water $\mathrm{pH}$ was measured after 24 hours' soaking. The $\mathrm{pH}$ values and the stage of decay are given in Fig. 1.

\section{Vegetation analysis}

The vegetation of the $\log$ s was analyzed in microquadrats sized $20 \times 20 \mathrm{~cm}$, the same method used for study of epiphytic associations in northeast Peru (Frahm 1987). Drawings of the communities were made on a piece of plastic (Fig. 2 ), and samples were taken of the species both within the quadrats and elsewhere on the logs. The species composition on different sized logs seemed to be variable: clear communities with a variety of species were situated randomly as patches or scattered along the log. Between them were areas of bare decaying bark or wood, and rarely stands of vascular plants. For this reason, no random sampling or regular sampling method was used; rather the quadrats were placed with the intention to include most of the communities. A total of 51 quadrats were laid out on the logs. The coverage of every species on the quadrat was calculated in percentages in the laboratory from the plastic outlines (Table 3). For analyzing the similarity of the sample plot descriptions Sörensen's QS-values were chosen (see Bates 1982, Slack 1984).

\section{Identification of specimens}

Many published records list the bryophyte flora of tropical East Africa (see Kis 1985, Ochyra \& Sharp 1988, O’Shea 1995), and the literature is wide and scattered (see Greene \& Harrington 1979, 1989). At the moment no bryophyte floras are useful for identifying the material. The lack of such literature made determination of the samples quite laborious, and many of the specimens are for the time being identified only to genus. All were segregated by species and given a tentative placement based on Kis' (1985) checklist plus a large number of recent monographs and revisions. The author Koponen identified the mosses to genus or family level and Sinikka Piippo identified all hepatic taxa. Johannes Enroth helped us in identification of Neckeraceae species and Marjo Anttila in Sematophyllaceae.

Within the total of 406 specimens collected from rotten wood are 320 specimens of mosses and 86 specimens of hepatics, and these represent 102 species. The hepatics which were identified only to genus level represent 16 genera. In addition we chose to use a collective taxon "Hepaticae" for cases in which the genus of a hepatic specimen could not be identified. Mosses were identified to species, or in some genera to infrageneric groups, for instance "Campylopus sp. 1". For cases in which the mosses in a certain genus represent a single unnamed species the expression "sp". is used. Within our material are 86 moss taxa. For distribution of taxa in different study areas see Table 2. The voucher specimens are permanently stored in the Herbarium of the Botanical Museum of Helsinki University $(\mathrm{H})$ and a duplicate set in the Herbarium of Sokoine University of Agriculture.

The nomenclature used follows, with a few exceptions that of Kis (1985). In life form terminology we have followed Mägdefrau (1982).

\section{RESULTS}

\section{Flora of rotten wood}

In the Usambaras a total of 38 taxa and on Mt. Meru a total of 73 taxa were sampled from rotten wood. Within the total of 102 taxa the flora of these mountains share 5 genera of hepatics; since specific determinations are lacking, a more accurate comparison cannot be done. Within the total of 86 species of mosses the Usambaras and Mt. Meru share only 4 species in common. The higher specific diversity shown for Mt. Meru may be caused by our higher research intensity there and by more varied habitats. 
The number of taxa sampled from rotten wood within each of 7 study areas varied from 14 to 55 (Fig. 3), with the lowest number of taxa sampled in Bulwa in Amani and the highest (remarkably higher than in the other study areas) on the eastern slope of Mt. Meru in Arusha National Park. On the western slope of Mt. Meru were 37 taxa. The number of taxa below the tree-line was 27 and above the tree-line 18 .

Within 102 taxa, $47 \%$ occurred on only one study site (Table 2). The most common taxon was the hepatic genus Plagiochila. On the Usambaras the following taxa or species were common:

\section{Callicostella spp.}

Campylopus sp. 1

Chiloscyphus sp.

Ectropothecium sp.

Leucobryum sp.

Rhacopilopsis trinitensis

Rhizogonium spiniforme

Rhynchostegium cf. comorae

Trichosteleum sp.

In the primeval forests of Mt. Meru the following taxa or species were common:

\section{Anacolia laevisphaera \\ Campylopus sp. 1 \\ Frullania sp. \\ Bryum sp. \\ Homalothecium afrostriatum \\ Hypnum cupressiforme \\ Orthodontium cf. gracile \\ Oxystegus tenuirostris \\ Papillaria cf. africana \\ Plagiochila sp. \\ Pterogonium gracile \\ Sematophyllum brachycarpum \\ Zygodon cf. intermedius}

In the cultivated monoculture forests on Mt. Meru these were not similarly common, but in these cultivated forests Haplocladium angustifolium and Rhynchostegium sp. occurred frequently.

The number of taxa within the study sites varied from 5 to 37 (Fig. 4), but these numbers give only a very rough picture of the diversity of the bryophyte flora on the study sites, because time available within each of the sites proved such a limiting factor. The most time could be devoted to the eastern slope of Mt. Meru, which may in part explain the higher numbers of taxa observed there.

\section{Bryophyte associations}

Epixylic plant communities in the study area consisted mostly of bryophytes, with the total coverage of bryophytes on the 51 plots ranging between $5 \%$ and $100 \%$, on average, $64 \%$. The vegetation on these rotten logs was composed mainly of mosses; hepatics occurred on only about half of the plots. The percentage cover of hepatics varied from + (less than $0.5 \%$ ) to $91 \%$, on average, $21 \%$. Lichens and fungi occurred on 11 plots, and their average coverage was $3 \%$. Vascular plants, mostly seedlings, were on 7 plots and their average cover was $4 \%$. This high number is due to plot 14 with its high cover of vascular plants. The percentage cover of taxa in the sample plots appears in Table 3.

Within the 51 sample plots, altogether 71 bryophyte taxa occurred; of them, 11 were hepatic taxa. Three genera of hepatics and 3 species of mosses occurred both in the Usambaras and on Mt. Meru; the other taxa occurred only in either of these locations. Within the study areas the numbers of taxa in sample plots varied from 4 in Lushoto to 20 in the primeval forest on the eastern slope of Mt. Meru (Fig. 5).

Most of the taxa, $42 \%$ occurred on only one sample plot. Two species, Leucobryum sp. and Hypnum cupressiforme, occurred on 9 sample plots, and the commonest species on the plots was Callicostella usambarica, which occurred on 12 plots. Common species were usually also abundant; common but sparse species were not recorded. In this material a typical bryophyte of rotten wood occurred on average on three sample plots out of 51. Each plot had 1 to 7 taxa, on average, 4 (Table 3 and Fig. 6).

The QS-values (Table 4) seem to indicate that the sample plots within a certain study area were 
stage of decay

$\mathrm{pH}$

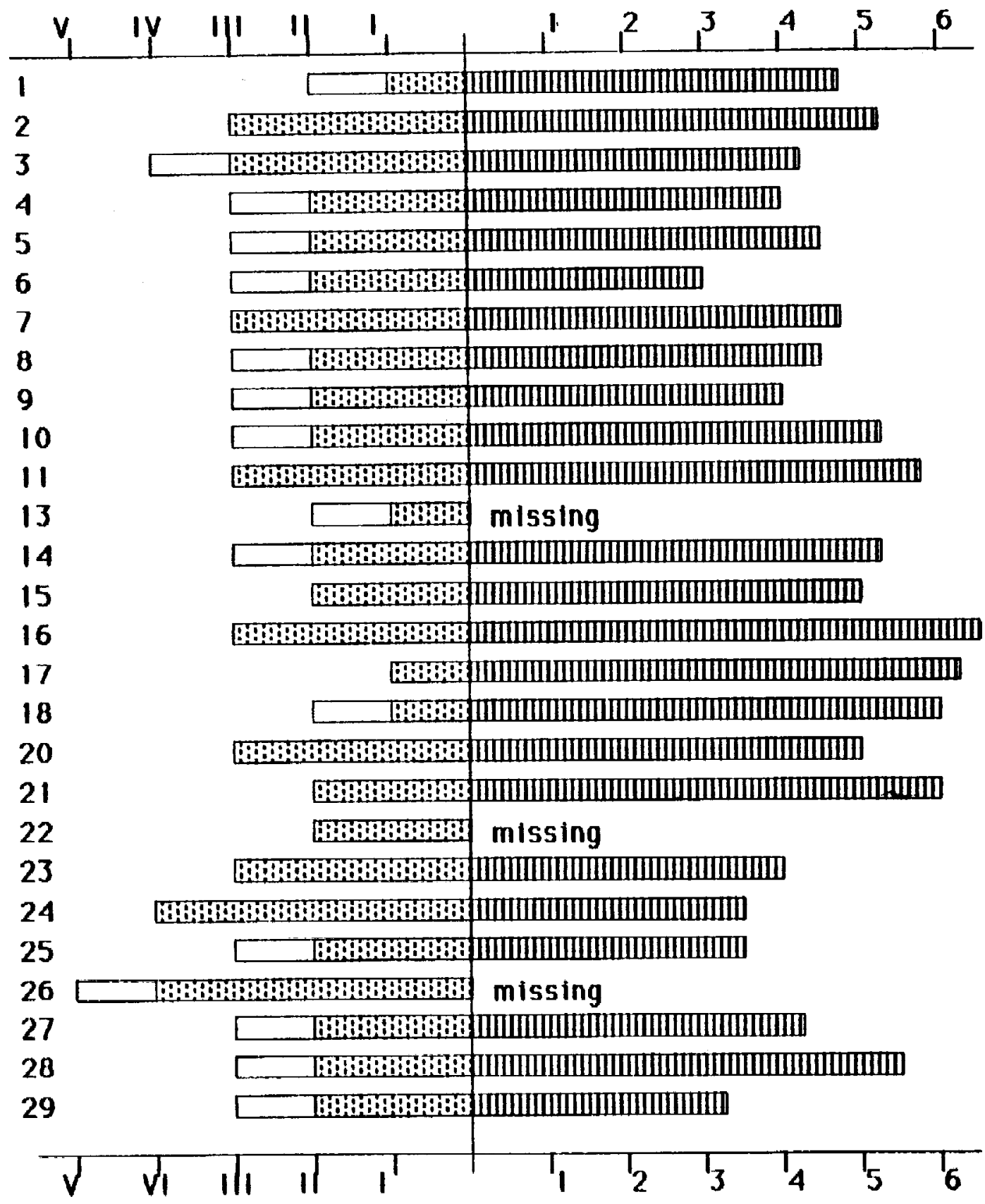

Fig. 1. (above) Stage of decay of logs studied (minus nos. 12,19) estimated in the field on a scale of $\mathrm{I}-\mathrm{V}$. A stage of decay estimated as I-II, is shown by the unstippled part of the diagram; $\mathrm{pH}$ values measured from dried samples of rotten wood ( $3 \mathrm{gr})$.

Fig. 2. (right) Quadrats $(20 \times 20 \mathrm{~cm})$ with bryophyte communities on decaying wood in northwestern Tanzania. 1. Quadrat 5, Callicostella-Ectropothecium-Thuidium community. 2. Quadrat 14, Leucobryum community. 3. Quadrat 15, Rhacopilopsis community. 4. Quadrat 22, Rhynchostegium community. 5. Quadrat 19, Trichosteleum community. 6. Quadrat 17, Chiloscyphus community. 


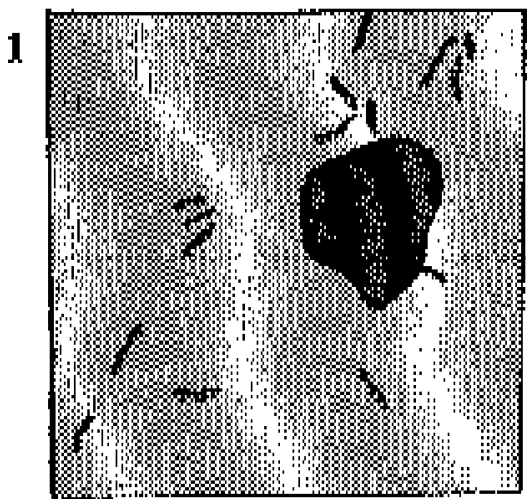

2

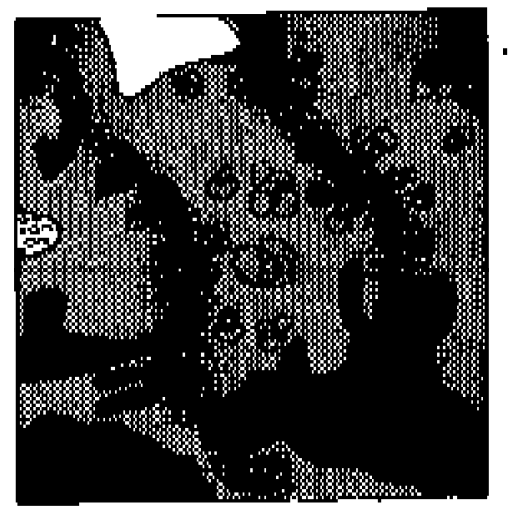

3

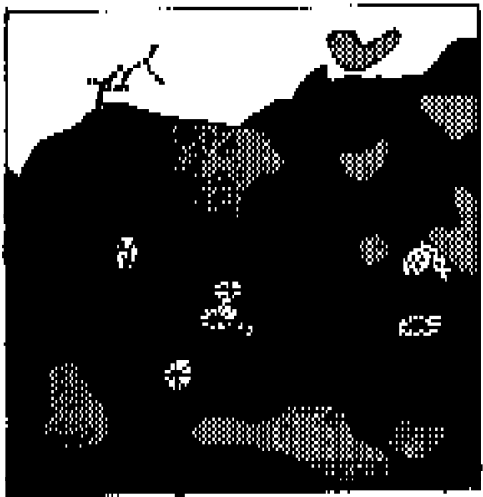

4

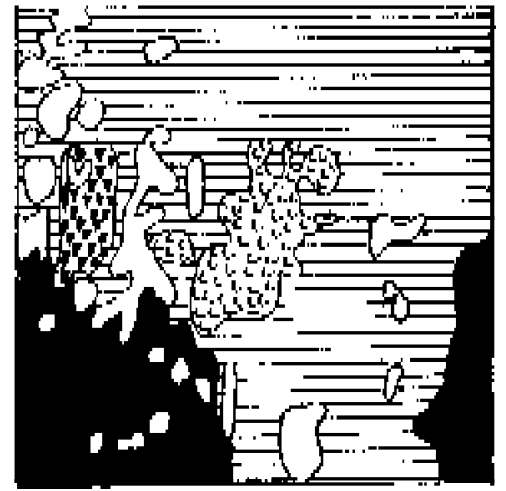

5
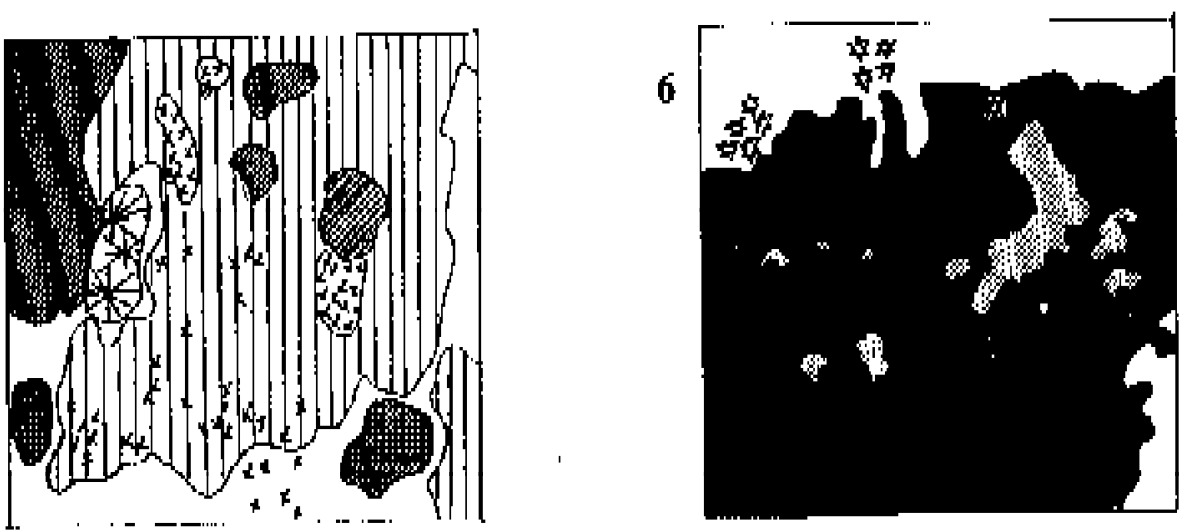

\begin{tabular}{|c|c|}
\hline & bare woodd \\
\hline 66 & Takglars \\
\hline & liethents \\
\hline & Chilnatyphus sp \\
\hline & Lejemea $t$ p. \\
\hline$C_{C}^{2} L_{b}^{2}$ & Finginchila . .p. \\
\hline
\end{tabular}
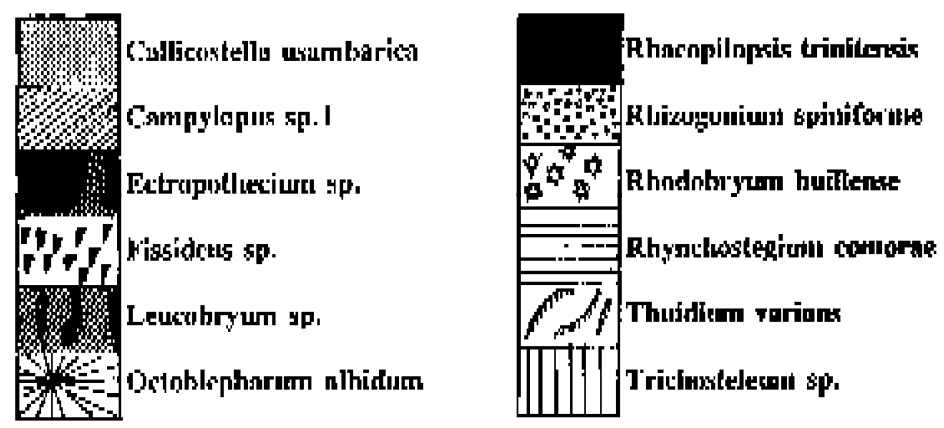
more similar to each other than they were to the plots of the other study areas. In the Usambaras the sample plots from Amani (Study Area 2) were very similar to each other and had many species in common. In the material from Bulwa (Area 1) the plots were less similar. Two sample plots in Lushoto (Area 3) were more similar to each other than to any other plots, and they had species (Fissidens sp., Chiloscyphus sp.) in common with the plots from Mt. Meru. On the western slope of Mt. Meru (Area 6) were certain species typical for that area, and some species common within the area. The sample plots on the eastern slope of Mt. Meru (Area 7) were more heterogeneous; the QS-values are rather low between them.

The material is not large enough for any detailed description of plant associations. We chose to name the communities on the basis of dominant taxa on the sample plots. By this method there occurred on rotten wood in our study area the following 15 bryophyte communities:

1. The Callicostella-Ectropothecium-Thuidium community

2. Leucobryum community

3. Rhacopilopsis

4. Isopterygium

5. Rhynchostegium

6. Trichosteleum

7. Chiloscyphus

8.Haplocladium-Rhynchostegium-Sematophyllum

9. Homalothecium

10. Pterogonium-Hepaticae

11. Zygodon

12. Oxystegus

13. Campylopus-Hypnum

14. Orthodontium

15. Oxystegus-Meteoriaceae .

The vegetation in the eastern Usambara Mountains in Amani (Area 2) represented Callicostella-Ectropothecium-Thuidium community; and to a smaller extent a Rhynchostegium community occurred there. In Bulwa (Area 1) occurred many different communities: Leucobryum, Rhacopilopsis, Trichosteleum, Isopterygium, and Chiloscyphus communities. In the western Usambaras (Area 


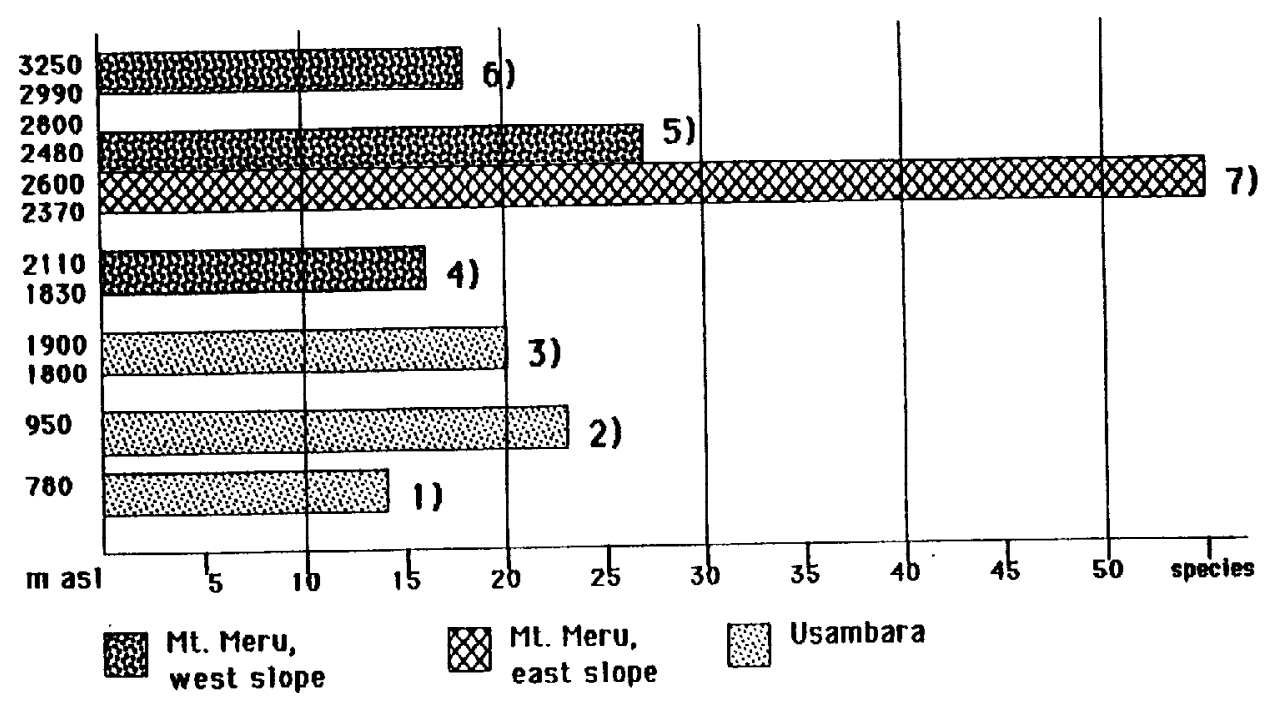

Fig. 3. Total numbers of bryophyte taxa on rotten wood in seven study areas in the Usambaras and on Mt. Meru. 1. East Usambara, Amani, Bulwa. 2. Amani. 3. West Usambara, Lushoto, Magamba. 4. Western slope of Mt. Meru; Olmotonyi, cultivated forests. 5. Olmotonyi, primeval forests below tree-line. 6. Olmotonyi, above tree-line. 7. Primeval forests on eastern slope of Mt. Meru, Arusha National Park. Altitudes above sea-level in meters.

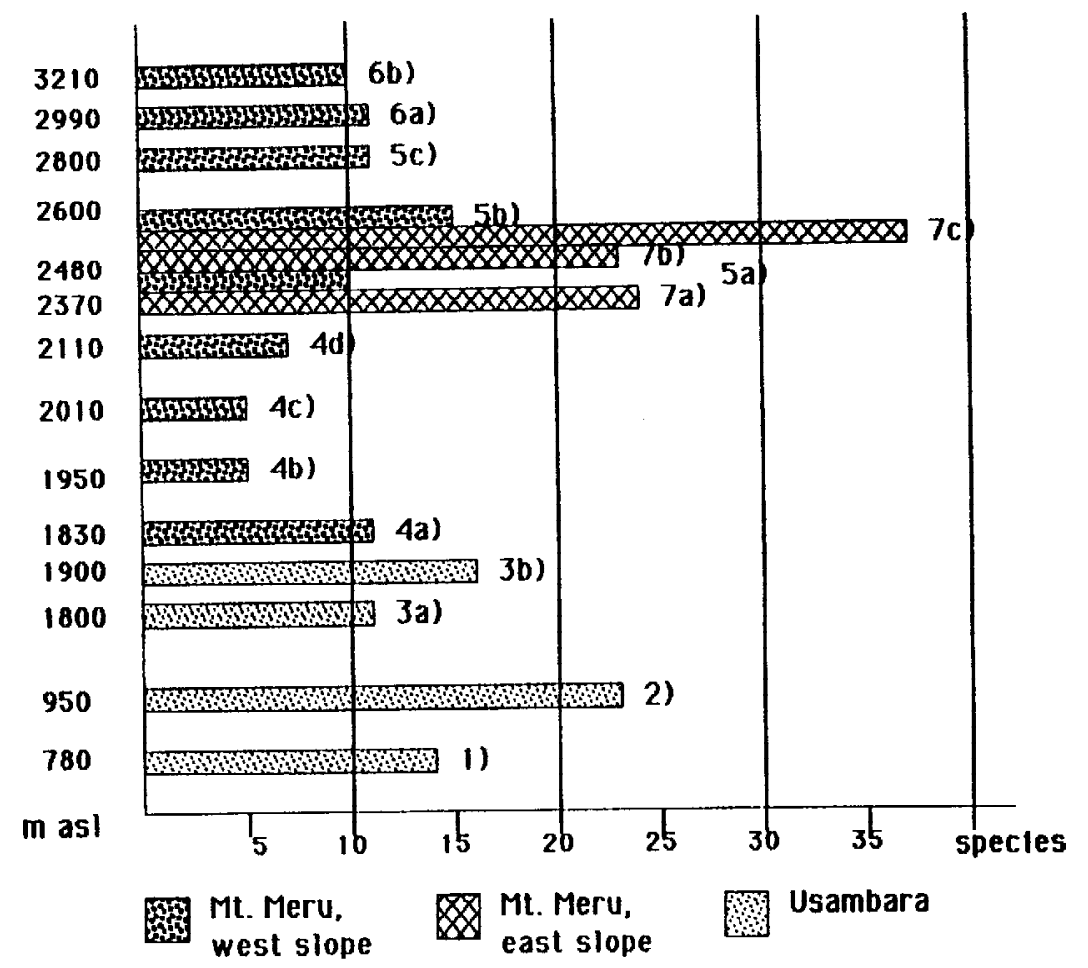

Fig. 4. Total numbers of bryophyte taxa on rotten wood in 16 study sites (nos. 1-7c), with 5 to 37 species on each site; the median was 15 (14.6) and CV \% was 58\%. Altitudes in meters. 


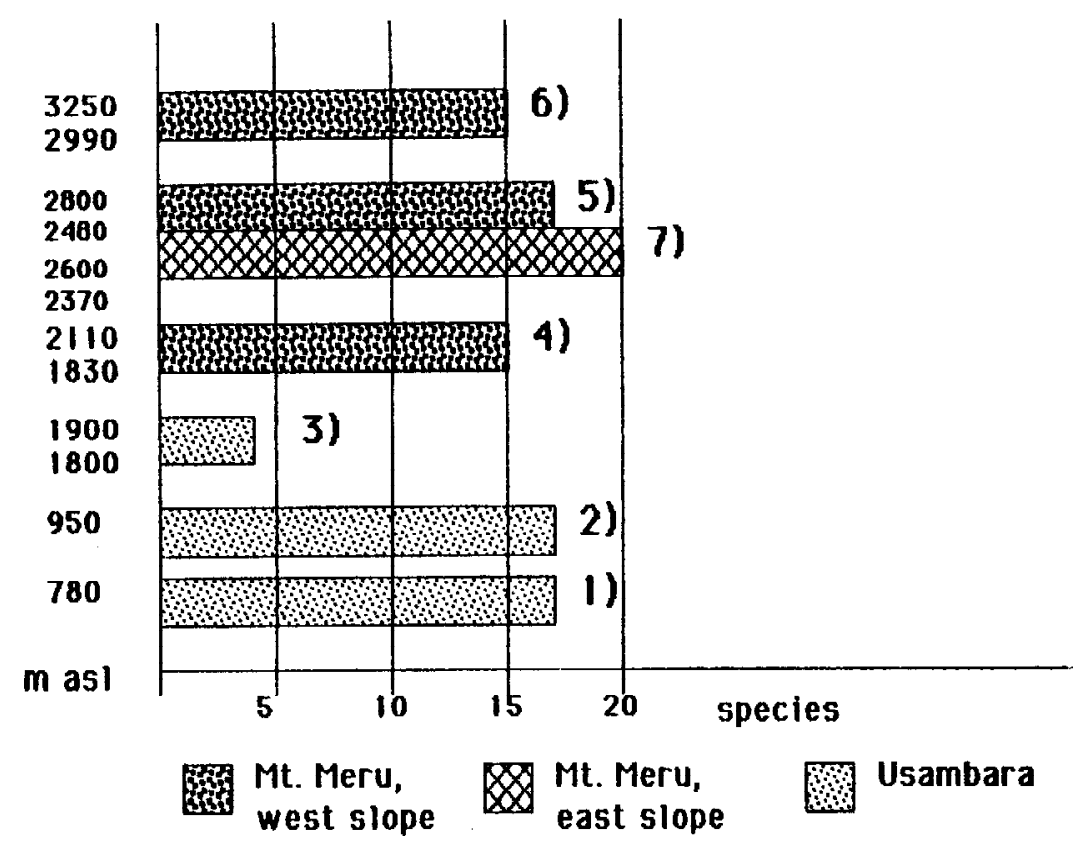

Fig. 5. Total numbers of bryophyte taxa on the sample plots $(20 \times 20 \mathrm{~cm})$ within the seven study areas (as in Fig. 3). Altitudes in meters.

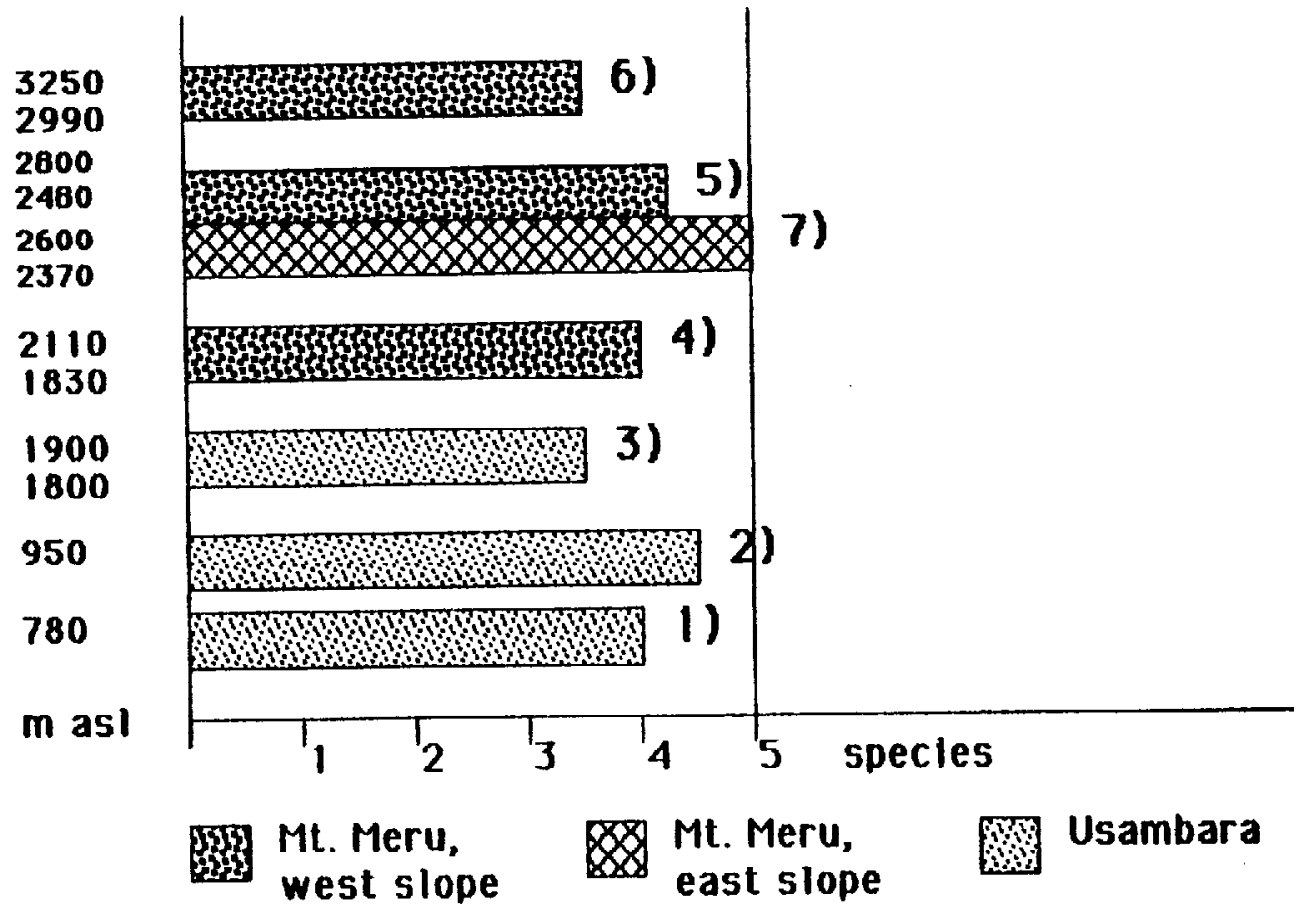

Fig. 6. The average number of bryophyte taxa on sample plots $(20 \times 20 \mathrm{~cm})$ within the seven study areas (as in Fig. 3). 
3) there occurred associations with the same dominants as in the eastern Usambaras: Rhynchostegium and Chiloscyphus communities.

The vegetation in the cultivated forests on Mt. Meru (Area 4) belonged to HaplocladiumRhynchostegium-Sematophyllum community. In the primeval forests on the western slope of Mt. Meru (Area 5) the characteristic communities were dominated by Homalothecium, Pterogonium-Hepaticae, Oxystegus, and Orthodontium. On the eastern slope of Mt. Meru, the most typical associations were OxystegusMeteoriaceae communities. Zygodon and Campylopus-Hypnum communities occurred in the primeval forests both on the eastern and western slopes of Mt. Meru.

\section{Life forms}

Within the material occurred 9 different life forms. Their proportions were calculated on the basis of the cover \% on 51 sample plots (Fig. 7). The weft form was most abundant, on $46 \%$ of the whole area. All the other life forms had a share of less than $20 \%$. Life forms from the most common to the rarest were: weft, mat, short turf, tail, cushion, tall turf, pendant, fan, and dendroid; the three forms listed last were equally rare. Taxa with the weft form were most common: 22 of 71 taxa. The cover percentages of the life forms, number of species belonging to each, and lists of genera classified according to life form appear in Table 5 .

In the Usambaras, the weft form was most common, $66 \%$ of the vegetation studied, while on Mt. Meru, weft and short turf forms together composed more than half $(53 \%)$ of the vegetation. In the sample plots from the Usambaras, pendant and fan forms were absent. The cushion life form, relatively common in the Usambaras, was absent from Mt. Meru (Fig 8).

The occurrence of different life forms within our 7 study areas showed remarkable differences (Fig. 9). In Amani (Area 2), on the majority of the plots the vegetation comprised weft form taxa
(Callicostella spp.) with some dendroid forms (Hypopterygium sp.). In Bulwa (Area 1), cushion, mat, and weft forms were equally abundant. In Lushoto (Area 3), the mat form was most common, accompanied by the weft form. In the cultivated forests on Mt. Meru (Area 4) weft and mat forms dominated, but short turfs and tail forms were present. In the primeval forests on the western slope of Mt. Meru (Areas 5 and 6), short turfs and tail forms were most common, but together with these, most other life forms also occurred there. In relation to the limits of the treeline these forms were divided so that below the tree-line tail and hanging forms were more common than above it, where tall turfs and weft forms were more common. Bryophyte vegetation in the primeval forests on the eastern slope of Mt. Meru was rather similar to that on the western side, except that the pendant form was abundant in the east.

\section{DISCUSSION}

\section{Flora and vegetation}

The vegetation on decaying and rotten wood in the rain and montane forests in northwestern Tanzania was composed mainly of bryophytes. Altogether 102 taxa were collected and identified from that substrate. On the basis of the dominant taxa 15 different communities were named, the sample plot material being too scanty for closer classification and ranking of the vegetation. On the basis of the material at least the following taxa were locally frequent and abundant on rotten wood:

\section{Callicostella spp.}

Campylopus spp.

Campylopus sp. 1

Chiloscyphus sp.

Ectropothecium sp.

Haplocladium angustifolium

Homalothecium afrostriatum

Hypnum cupressiforme

Isopterygium spp.

Leucobryum sp.

Orthodontium cf. gracile

Oxystegus tenuirostris 


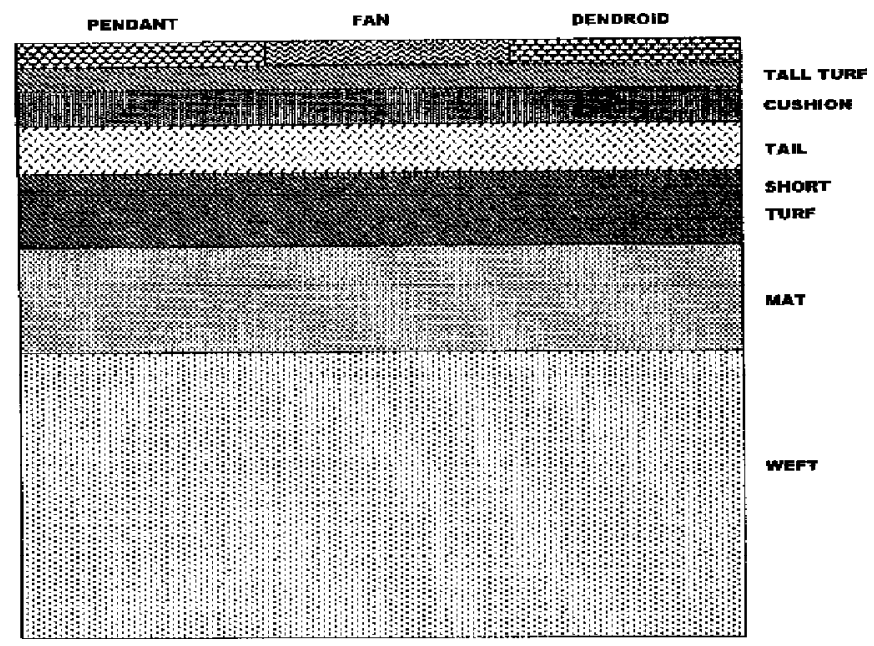

Fig. 7. Cover by 9 life forms of the bryophytes on rotten wood in northeastern Tanzania, taxa grouped according to life forms (Table 5), and total cover combined for taxa of each life form on 51 sample plots $\left(20 \times 20 \mathrm{~cm}\right.$, total cover $\left.2.04 \mathrm{~m}^{2}\right)$. Weft form most abundant, pendant, fan, and dendroid forms are the scarcest.

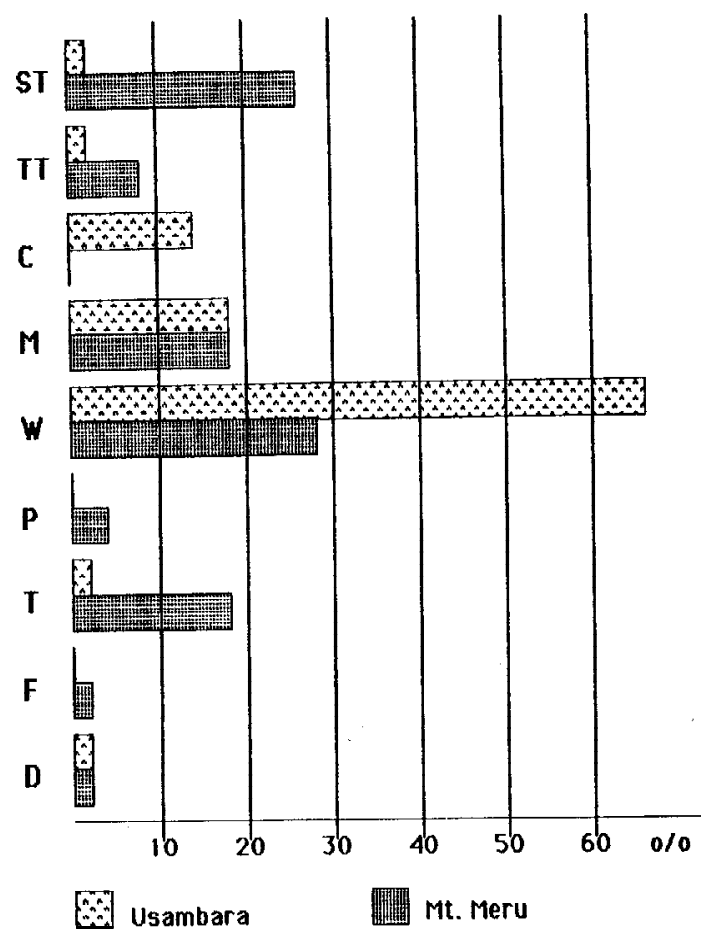

Fig. 8. Occurrence of 9 life forms on 51 sample plots $(20 \times 20 \mathrm{~cm})$ in the Usambaras and on Mt. Meru. The share of each life form on the sample plots as a percentage. ST $=$ short turf, TT $=$ tall turf, $\mathrm{C}=$ cushion, $\mathrm{M}=$ mat, $\mathrm{W}=$ weft, $\mathrm{P}=$ pendant, $\mathrm{T}=$ tail, $\mathrm{F}=$ fan, $\mathrm{D}=$ dendroid. 

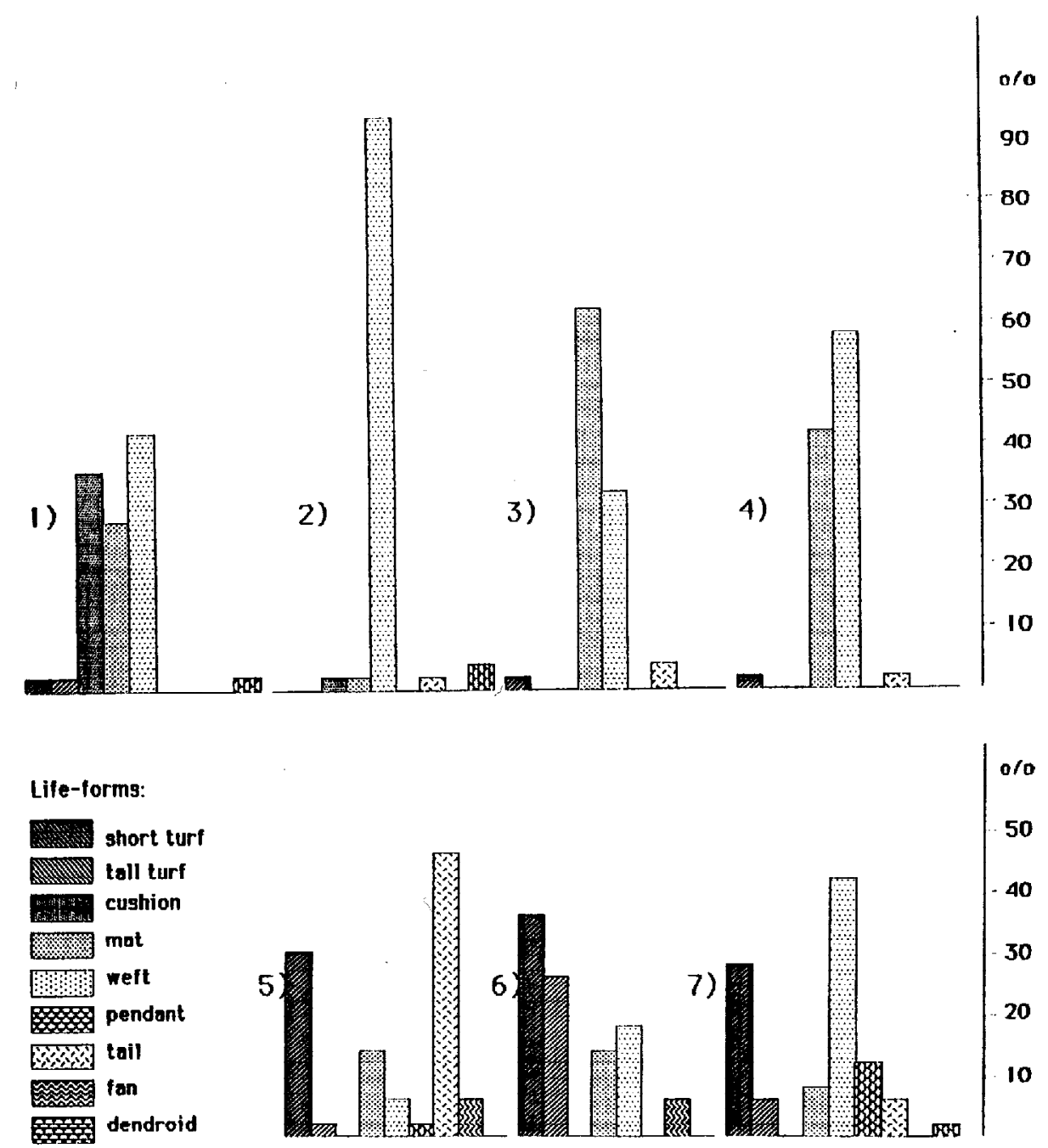

Fig. 9. Occurrence of 9 life forms in seven study areas (as in fig. 3), with share of each life form in percentage of total vegetation cover in each area.

Rhacopilopsis trinitensis

Rhizogonium spiniforme

Rhynchostegium spp.

Pterogonium gracile

Sematophyllum spp.

Thuidium spp.

Trichosteleum sp.

Zygodon spp.

The geographical position of the study area had a clear influence on its flora. The Usambaras and Mt. Meru are isolated from each other by a dry unforested area, and, on the basis of the present material their floras of rotten wood differed greatly. Usambara is a well-known center of endemism (e.g. Lovett 1985), but this was not seen in the flora on rotten wood; Mt. Meru had a richer flora. It is possible that in the lowland tropical rainforest the limiting factor for a diverse flora is the rarity of the substrate. The decomposition of the wood is so quick that suitable substrates are rare or in existence only a short time. In continuously moist and cool montane forests, as on Mt. Meru, the decomposition is slower, and species of rotten 
Table 4. Similarity values (QS values, cf. Slack 1984) for 51 sample plots based on the presence of the species on the plots; the higher the value the more similar the plots $(-=$ similarity is $0 \%)$. Values within each study area (Fig. 3) in boxes. 
Table 5. Life forms and distribution of their bryophyte taxa. Percentage and number of species (taxa) belonging to each of the life-form classes and genera belonging to each life-form class; material comes from 51 sample plots.

short turf

$13 \div$

14 species (Fissidens, Syrrhopodon, Barbula, Leptodon tium, Oxystegus, Tortula, Brachymenium, Bryum, Orthodontium, Ptychomitrium, Zygodon spp.)

tall turf

7 species (Campylopus, Octoblepharum, Rhizogonium, Anacolia, Bartramia spp.)

\section{cushion}

1 species (Leucobryum sp.)

mat

$18 \%$

14 species (Hepaticae; Chiloscyphus, Lejeunea, Metzger ia, Lophozia, Frullania, Jungermannia, Riccardia, Radula, Schwetschkea, Isopterygium, Sematophyllum spp.)

weft

$46 \%$

22 species (Lepidozia, Racopilum, Braunia, Floribun daria, Callicostella, Haplocladium, Thuidium, Brachythecium, Rhynchostegium, Trichosteleum, Wijkia, Ectropothecium, Hypnum, Rhacopilopsis, Vesicularia spp.)

\section{pendant}

3 species (Papillaria, Pilotrichella, Meteorium spp.)

tail

(Plagiochila, Leucodon, Pterogonium, Pterobryum, Aerobryidium, Homalothecium spp.)

\section{fan}

2 species (Neckera, Porotrichum spp.)

\section{dendroid}


wood have more time to spread. In montane forest the substrate specificity of bryophytes is not very strict; a certain species may grow on soil, on rotten wood, or as an epiphyte.

Climatic conditions do not, however, explain all the difference in the floras between old Precambrian mountains (the Usambaras) and younger volcanos (Mt. Meru). In these two areas, the floras differed in areas where the climatological conditions were similar. This difference may result from historical causes: The old Madagascar elements are present only on the Precambrian mountains, and they may have endemic taxa (Pócs 1976, 1980, 1982).

According to Richards (1984), in the lowland rain forests the number of hepatics is usually higher than that of mosses, and the scarcity of mosses is even striking. In the present material the flora of rotten wood both in the lowland rainforest and in montane forest was composed mostly of mosses. On only half of our sample plots did hepatics occur, and their cover on average was $21 \%$. In the lowland rainforests of South America the bryophyte vegetation mainly comprises mat form (carpet-forming) taxa, such as species of the families Sematophyllaceae and Hookeriaceae. Sometimes acrocarpic species such as Leucobryum sp. and Octoblepharum albidum occur. Hepatics occur, but less that epiphytic ones (Richards 1984). This agrees with our results; weft and mat forms composed more than half of the vegetation on our sample plots (Fig. 7).

According to Pócs (1982), the bryophyte vegetation on rotten wood in lowland rain forests is composed of mat and weft form species, such as Lophocolea sp., Chiloscyphus sp., and Callicostella sp., and other taxa of the family Hookeriaceae. In addition, he mentioned as typical Thuidium spp., species of Sematophyllaceae (e.g., Trichosteleum sp.) and Hypnaceae, dendroid Hypopterygium spp., and turf or cushion-form Campylopus, Leucobryum, Leucophanes and Rhizogonium species, and the species of Calymperaceae. The submontane communities described in the present work fit Pócs' (1982) description. In the montane forests the situation was different; Mt. Meru had more life forms present and the vegetation was more heterogeneous than in lowland rainforest or submontane rainforest.

According to Richards (1984), in humid montane forests of South America the flora of rotten wood is rich both in abundance and species; hepatics are especially abundant. However, no studies cover the structure of its vegetation, only lists of species. In our material, the hepatic taxa do not become markedly more common or abundant along the altitudinal gradient.

\section{Influence of substrate on flora and vegetation}

The rotten logs studied represented all five stages of decay. However, the intermediate stages were most frequently sampled (Fig. 1). Since the floristic differences between different study areas were great, the substrate in relation to the flora and vegetation can be discussed only regarding each of the seven study areas. In none of the study areas did the rotten $\log$ s form a complete series of stages of decay (I-V), and hardly any clear evidence can be found of possible succession of the vegetation ( e.g. in Area 1, all the logs were stages II-III).

In Amani (Study Area 2) typical species on wood, which was not much decayed and still had bark were Ectropothecium sp., Leucobryum sp. and Rhodobryum huillense. No correlation was found between stage of decay and occurrence the species of Callicostella, Rhynchostegium comorae, or Thuidium varians; all these occurred abundantly on logs at any stage of decay.

In the cultivated forests of Mt. Meru (Area 4) the logs and stumps represented stages I-III, but no differences could be discovered in the flora.

In the primeval forests on the western slope of Mt. Meru (Area 5), a number of species were present only on wood at lower stages of decay, or were more abundant on such a substrate than elsewhere. These were Lejeunea sp., Frullania sp., Tortula sp., Anacolia laevisphaera, Papillaria africana, Neckera submacrocarpa, and Homalothecium afrostriatum. On the eastern 
slope of Mt. Meru (Area 7), the following taxa were common on the logs at low stages of decay: Leptodontium sp. 3, Bryum sp., Papillaria africana, Pilotrichella ampullacea, and Rhacopilopsis trinitensis. On logs at higher stages of decay Campylopus sp. 1, Leptodontium sp. 2, and Hypnum cupressiforme appeared.

As already mentioned, this material had only very few indications of vegetation succession on rotten wood. However, on the eastern slope of Mt. Meru the communities with typical epiphytic species might represent the first stage of succession, which is the change in vegetation from epiphytic to epixylic. On the other hand, this succession might be due to the lesser degree of substrate specificity. According to Pócs (1982), the first stages of vegetation succession on rotten wood in montane forests corresponds to the vegetation on the base of the trunks of living trees. As decay proceeds, these epiphytic communities are replaced by more specialized communities of rotten wood, which may in part be mycotropic. Because our studies on the epiphytic communities in our study areas are not yet completed, we cannot yet offer any conclusive facts.

The $\mathrm{pH}$ values and stage of decay did not correlate with each other (Fig. 1). Logs at the low stages I-II had a pH of 4.71-6.06, while the logs representing stages III-IV had a $\mathrm{pH}$ of 3.406.32. The lowest $\mathrm{pH}$ measured, 2.96, was for $\log$ no. 6 which was at stage II-III of decay. This discrepancy is probably due to our methods: stage of decay was estimated from several points on each $\log$, whereas $\mathrm{pH}$ was measured from the surface of the $\log$ and from the immediate neighborhood of the vegetation. Stage of decay illustrates the time which has elapsed after the death of the tree, while $\mathrm{pH}$ indicates the substrate circumstances right at the time a study is made. However, it can be stated that Homalothecium and Pterogonium-Hepaticae communities grew on a nearly neutral substrate ( $\mathrm{pH}$ ca 6 ). In these communities there occurred species which are considered epiphytes (Neckera submacrocarpa, Papillaria africana, and Porotrichum sp.), vegetation which represents the first phase of succession on rotten wood, during which time epiphytic species are replaced by epixylic taxa.
It seems obvious that larger material and more accurate observations of the age of the substrate are necessary to study the succession on rotten wood in tropical conditions.

\section{Life forms and life strategies of bryophytes on rotten wood}

The life forms or life forms of bryophytes reflect to some extent their ecophysiological adaptation and, on the other hand, the ecological circumstances of the habitat (Gimingham \& Birse 1957, Richards 1984). In addition, life forms are in positive correlation with the life strategies of bryophytes (Joenje \& During 1977). During (1979) established six types of life strategies for bryophytes, using their reactions to fluctuations in the environment, especially their amplitude and predictability. Rotten wood as an environment is rather constant and predictible, but it disappears after a certain period. According to During (1979), the species in such environments represent a perennial shuttle strategy, and their life forms are cushion, mat, and tuft forms. In more stable conditions the bryophytes represent weft, dendroid, mat, or sometimes cushion forms, and are usually species of fens, bogs, and forest floor. Our study in tropical forests does not completely support During's classification, since the most common life form on rotten wood was the weft form, often accompanied by the dendroid form. According to Mägdefrau (1982) the weft, tail, and fan forms thrive in shady habitats. The pendant form is typical in tropical mossy forests. All these life forms occurred on rotten wood in our study areas in the tropical forest. This may indicate that During's (1979) life strategy classification based mainly on vegetation in temperate and boreal conditions does not apply in tropical conditions; a conclusion During (1992) later expressed.

Söderström (1987a, 1987b, 1988a, 1988b) has studied the bryophyte vegetation on rotten wood and the dispersal of species in boreal forests. He describes core species, which are common and locally abundant, and satellite species, which are rare and scarce. In our material, most part of the 
epixylic taxa were rare and were recorded only once or twice, and their cover percentage was always low (Table 3). On the other hand, some other taxa were common within separate study areas and dominated the vegetation. This seems to indicate that the theory of core species - satellite species (e.g., Hanski 1982) can be applied to the bryophyte vegetation on rotten wood in tropical forests. This should be confirmed by monitoring experiments.

\section{Points for nature conservation}

Our results, although preliminary, seem to indicate that, on rotten wood in northeastern Tanzania, within rather short distances quite different floras and plant associatons occur. The floras on Mt. Meru and on the Usambaras differ from each other almost totally. This imposes certain conditions for conserving their biological diversity. It is not enough to protect the highelevation montane forests, but samples of all vegetation types should be conserved. Moreover, because the floras of planted monocultures are quite different from those of primeval forest, planted forests thus do not preserve the original biodiversity. These facts must be considered in planning the preservation of biodiversity.

\section{Acknowledgements}

We thank the Finnish Development Agency (FINNIDA) for providing funds which made the field research possible, and the Finnish Biological Society 'Vanamo' for a grant to the senior author. We also thank our colleagues who helped us in the identification or in many other ways.

\section{References}

Bates, J.W. 1982. Quantative approaches in bryophyte ecology. In: Smith, A.J.E. (ed.), Bryophyte ecology: 1-44. Chapman \& Hall, London.

During, H.J. 1979. Life strategies of bryophytes: a preliminary review. Lindbergia 5: 2-18.

During, H. J. 1992. Ecological classifications of bryophytes and lichens. In: Bates, J. W. \& Farmer, A. M. (editors), Bryophytes and Lichens in Changing Environment: 1-31. Clarendon
Press, Oxford.

Frahm, J.-P. 1987. Struktur und Zusammensetsung der epiphytischen Moosvegetationen in Regenwäldern NO-Perus. Beihefte zur Nova Hedwigia 88: 115-141.

Gimingham, C.H. \& Birse, E.M. 1957.Ecological studies on growth form in bryophytes. Journal of Ecology 45: 533-545.

Greene, S.W. \& Harrington, A.J. 1979. The bryological litterature of Africa, together with some Atlantic and Indian Ocean Islands. 141 pp. Natural Environment Research Council, Penicuik.

Greene, S.W. \& Harrington, A.J. 1989. The conspectus of bryological taxonomic literature 2. Guide to national and regional literature. 321 pp. Bryophytorum Bibliotheca 37, J. Cramer, Berlin, Stuttgart.

Hanski, I. 1982. Dynamics of regional distribution: the core and satellite species hypothesis. Oikos 38: 210-221.

Joenje, W. \& During, H.J. 1977. Colonisation of a desalinating Wadden-polder by bryophytes. Vegetatio 35: 177-185.

Kiirikki, M. 1990. On the field-layer vegetation in forest plantations in northeastern Tanzania. In: Koponen, T., Niemelä, T., Härkönen, M. \& Koponen, A. (ed.), Vegetation and ecology of the Tanzanian montane and rain forests. Final report of FINNIDA Project no. 282097 01-1: 99-104. Helsinki

Kis, G. 1984. Checklist of the mosses of south-east tropical Africa. In: Vána, J. (ed.), Proceedings of the third meeting of the bryologist from central and East Europe: 217-282. Univerzita Karlova, Praha.

Koponen, T., Niemelä, T., Härkönen, M. \& Koponen, A. (ed.) 1990. Vegetation and ecology of the Tanzanian montane and rain forests. Final report of FINNIDA project no. 282 097 01-1. 145 pp. Helsinki.

Lovett, J. 1985. Moist forests of Eastern Tanzania. Swara 8(5): 8-9.

Mägdefrau, K. 1982. Life-forms of bryophytes. In: Smith, A.J.E. (ed.), Bryophyte ecology: 45-58. Chapman \& Hall, London.

McCullough, H.A. 1948. Plant succession on fallen $\operatorname{logs}$ in a virgin spruce-fir forest. Ecology 29: 508-513.

Muhle, H. \& LeBlanc, F. 1975. Bryophyte and lichen succession on decaying logs I. Analysis along an evaporational gradient in Eastern Canada. Journal of the Hattori Botanical Laboratory 39: $1-33$.

Ochyra, R. \& Sharp, A.J. 1988. Results of a 
bryogeographical expedition to East Africa in 1968 IV. Journal of the Hattori Botanical Laboratory 65: 335-377.

O'Shea, B. 1995. Checklist of the mosses of subSaharan Africa. Tropical Bryology 10: 91-198.

Pócs, T. 1976: Correlation between the tropical African and Asian bryofloras I. Journal of the Hattori Botanical Laboratory 41: 95-106.

Pócs, T. 1980. The epiphytic biomass and its effect on the water balance of two rain forest types in the Uluguru mountains (Tanzania, East Africa). Acta Botanica Academiae Scientiarum Hungaricae 26: 143-167.

Pócs, T. 1982. Tropical forest bryophytes. In: Smith, A.J.E. (ed.), Bryophyte ecology: 59-104. Chapman \& Hall, London.

Pócs, T. 1990a. Excursion to the East Usambara Mountains, near Amani. Publications from the Department of Botany, University of Helsinki 16: $97-101$

Pócs, T. 1990b. Excursion to the Mt. Meru, near Olmotonyi. Publications from the Department of Botany, University of Helsinki 16: 111-116.

Richards, P.W. 1984. The ecology of tropical forest bryophytes. In: Schuster, R.M. (ed.), New manual of bryology, Vol. 2: 1233-1270. Hattori Botanical Laboratory, Nichinan.

Sastre-DeJesús, I. 1992: Estudios preliminaires sobre comunidades de briofitas en troncos en decomposición en el bosque subtropicaö lluvioso de Puerto Rico. Trop. Bryol. 6: 181-191.
Slack, N.G. 1984. A new look at the bryophyte community analysis: field and statistical methods. Journal of the Hattori Botanical Laboratory 55: 113-132.

Söderström, L. 1987a. Dispersal as a limiting factor for distribution among epixylic bryophytes. In: Pócs, T., Simon, T., Tuba, Z. \& Podani, J. (ed.): Proceedings of the IAB conference of bryoecology. Symposia Biologica Hungarica 35: 475-484. Akademiai Kiado, Budapest.

Söderström, L. 1987b. The regulation of abundance and disribution patterns of bryophyte species on decaying $\operatorname{logs}$ in spruce forests. $21 \mathrm{pp}$. Department of Ecological Botany, University of Umeå.

Söderström, L. 1988a. Sequence of bryophytes and lichens in relation to substrate variables of decaying coniferous wood in Northern Sweden. Nordic Journal of Botany 8: 89-97.

Söderström, L. 1988b. The occurrence of epixylic bryophyte and lichen species in an old natural and a managed forest stand in Northeast Sweden. Biological Conservation 45: 169-178.

Tuomisto, H. 1990. Vegetation and flora of natural forests along a transect on Mount Meru, northeastern Tanzania. In: Koponen, T., Niemelä, T., Härkönen, M. \& Koponen, A. (ed.), Vegetation and ecology of the Tanzanian montane and rain forests. Final report of FINNIDA Project no. 282 097 01-1: 105-110. Helsinki. 